\title{
Reduced Particle Recycling from Topographically Modified Graphite Surfaces \\ - Non-saturable walls in toroidal devices -
}

\author{
Y. Hirooka and R.W. Conn
}

UCLA-PPG-1218 August, 1988

\section{DISCLAIMER}

\begin{abstract}
This report was prepared as an account of work sponsored by an agency of the Uniled States Gowernment. Neither the United States Government nor any agency thereof, nor any of their employees, makes any warranty, express or impliod, or assumes any legal liability of responsibility for the accuracy, completeness, or usefulness of any information, apparalus, product. of process disclosed, of represents that its use would not infringe privately ow ned rights. Reference herein lo any specifie commercial product. process. or service by trade name, Iridemark. manufacturer, or otherwise does not necessarily constitute or imply its endorsement, recommendation, or favoring by the Uniled States Government or any agency thereof. The views and opinions of authors expressed herein do not necessarily stale of reflect those of the United Stales Government or any agency theroof.
\end{abstract}

Institute of Plasma and Fusion Research

Department of Mechanical, Aerospace, and Nuclear Engineering

University of Califomia, Los Angeles

Los Angeles, CA, 90024, U.S.A.
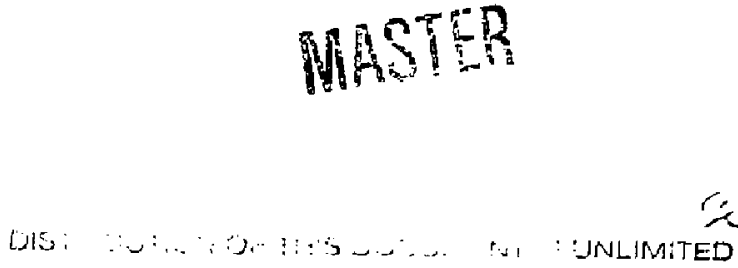


\section{DSCLAMER}

This report was prepured as an sccount of wark sponsored by an agency of the Uniled Suter Government. Neither the United Stutes Governmeat nor any esency thereaf, nor eny of their mplayes, mites sny warminy, expecss of implies, of susmes eny lezal Ifability or responaibility for the eceuracy, completenes,, or usefulness of eny information, apparuus, prodtet, or procens dieclosed, or represents that its ure would nor infringe privalely owned rights. Referenes herein to any specific eommercial product, process, of ecrvice by trade neme, oredernat, monufacurer, or otherwise, does not necessurily conutitute of imply its endorement, recournendation. Or fevoring by the United States Government or any agency thereof. The views and opinions of authers expressed herein do not nictivaily stale or reflect those of the United States Government of any agency thereor. 


\section{Brief overview of graphite wall pumping effects}

Pumping of hydrogen plasma particles by graphite surface components, such as limiter and divertor plate, has recently generated considerable attention in the PSI-community. The physics associated with the wall pumping effect is that the recycling neutral density in the edge-plasma region is reduced due to pumping by the plasma-facing component and this leads to an improvement of confinement of the core plasma.

The first observation of the wall pumping phenomena of this kind was made in JET late in 1985. In TFTR, the pumping effect by the graphite inumper limiter triggered the supershots early in 1986. Immediately after this, SNLL and SNLA made major efforts to understand the surface physics associated with wall pumping erfects in TFTR, using the ion beam facilities. Late: in 1986, the first off-line plasma simulation experiment of wall pumping was initiated at UCLA, PISCES. In 1987, similar wall pumping effects were observed in DIII-D. Also, in 1988 the reduced recycling associated with wall pumping has been observed in TEXTOR with ALT-II.

As such, wall pumping effects have been observed in major tokamaks and have many laboratories start a variety of new simulation experiments. However, it is also true that there is no single theory to interpret all the wall pumping phenomena observed so far. Currently, the following mechanisms are proposed:

(1) transient pumping due to particle in/out-flux imbalance (JET);

(2) pumping along with refilling emptied trapping sites (TFTR, SNLL, SNLA);

(3) continuous pumping due to codeposition (TFTR, SNLL, SNLA);

(4) pumping by plasma-activated porous surface (DII-D, TEXTOR, FISCES);

(5) combination of (3) \& (4) by a "machine-grooved" surface (PISCES).

It has been found that the pumping effects represented by ( 1 ) and (3) do not require any pre-conditioning of the wall. The rest seem to follow He-plasma conditioning. For mechanism (4), the pumping capacity has been found to depend up on the surface porosity of graphite materials. The mechanisms (3) and (5) can provide continuous and nonsaturable particle pumping. The non-saturable pumping capability is important in controlling the recycling in a long-pulse device such as ITER and beyond. It is, therefcre, essential that characteristics of the co-deposited (redeposited) layer be investigated. Yet one should bear in mind that co-deposition will continuously increase the tritium inventory as has been found in TFTR. For convenience, these observations are summarized in Table 1. 


\section{Wall pumping experiments in PISCES-A}

\section{Enhanced hydrogen pumping by surface porosity}

Plasma bombardment of graphite with inert gas (He,Ar) in PISCES-A (see Fig. 1, table 2) has been found to significantly increase sufface pore openings of low density isotropic graphites such as POCO-graphite (see Fig. 2). This inert-gas plasma bombarded graphite surface is found to be highly adsorptive scch that a large amount of neutral gases can be gettered and hence the recycling of hydrogen is drastically reduced when the activated surface is exposed to a hydrogen plasma (see Fig. 3). These observations have been consistently explained by the effect of 'line-of-sight' openings of surface pores in which low energy neutral particles are stored temporarily under high-flux hydrogen plasma bombardment (see Fig. 4). The surface, once saturated with hydrogen, can be easily reactivated via plasma impact desorption (see Fig. 5). The initial inert-gas plasma bombardment process is called 'Plasma-Activation-Process (PAP)' and the resultant plasma bombanded graphite surface introduced with high porosity and gas adsorptivity is referred to as 'Plasma-activated' graphite. These new jargons from the PISCES-group have been already used in the PSI community.

Only a year ago this unique 'porosity-induced transient pumping' concept was not even considered as a possible explanation to observations by the apathetic majority of the community. Now this concept receives increasing attention as related phenomena are observed in major tokamaks such as DII-D. In this regard, the PISCES group and DIII-D group worked together in understanding the graphite pumping effects which are not al ways consistent with those found in TFTR in 1987. Obviously, this porosity-induced pumping effect relevant to the observations made in JET recently although the researchers at JET have not admitted the validity of this concept. Details have been recently published in the Joumal of Vacuum Science \& Technology-A.

\section{Non-saturable pumping by surface topographical modification}

For future long-pulse devices like ITER, the transient pumping can not significantly contribute to controlling the paricle balance in the edge plasma region. In response to this question, the PISCES group has already come up with one possible solution by using 'artificial' co-deposition effects. The co-deposition effect has been observed in tokamaks 
and recognized as one of the 'unavoidable (natural)' processes to deposit hydrogen together with eroded materials on the surface. The 'artificial' co-deposition in PISCES has been observed for a topographically modified surface of graphite. This co-deposition can be induced by topographical modifications such as machined-grooves on the surface (see Fig. 6 ).

The first experiments in PISCES-A demonstrated $20 \%$ continuous reduction of the recycling rate from a machine-grooved graphite surface (see Fig. 7). Also, 10-15\% reduction in the emission of impurities such as chemically sputtered hydrocarbon and physically sputtered carbon (see Fig. 8). Consistently with these findings, a codeposited film is found within the groove. The co-deposited material has been observed to have characteristic dendritic features (sec Fig. 9). These results have been presented at the recent Inc Conf. on PSI at Julich and has received considerable attention from the audience. This is because $20 \%$ reduced recycling in the edge area can easily induce a significant increase in the core plasma temperature in a tokamak (eg. TEXTOR). This idea of topographyinduced pumping effects can be applied for tokamak fusion experiments via adjusting the groove angle and dimention to the local plasma particle flow direction and the gyro-radii of the particles.

\section{Non-saturable walls in toroidal devices}

As mentioned above, it is possible to apply the wopraphy-induced effects on hydrogen pumping and impurity emission to toroidal devices. Several criteria should be satisfied, namely, (1) the groove openings be oriented to the particle flow guided by the magn ic field line (2) the groove spacing be equivalent to the gyro radius. (3) the groove depth be deeper than the ion gyration distance (4) the particle incident energy be moderately high = $100 \mathrm{eV}$ (5) the wall temperature be controlled to avoid thermal decomposition of $\mathrm{C} \cdot \mathrm{H}$ codeposits (not higher than the baking temperature).

Pre-implanted deuterium can be released from the machined grooves via helium plasma impact desorption (see Fig. 10). Also, removal of the codeposited layer can be done by high-fluence helium plasma bombardment, as has been demonstrated recently in PISCESA. After helium plasma desorption, enhanced wall pumping is seen. However, this enhancement is temporary as opposed to the topography-induced codeposition effect. To 
remove pre-implanted deuterium (tritum) from the grooved surface, one might also try hydrogen discharges. Because of the smaller ion gyration, hydrogen can penerrate deeper than helium into the groove where one finds codeposited lavers. The deuterium removal behavior by hydrogen plasma impact is being investigated in PISCES-A.

\section{Relevant publications from PISCES}

1. "Hydrogen pumping and release by graphite under high-flux plasma bombardment" Y.Hirooka, W.K.Leung, R.W.Conn, D.M.Goebel, B.Labombard, R.Nygren and K.L.Wilson

Journal of Vacuum Science and Technologies-A 6(1988)2965.

2. "Deuterium pumping and erosion behavior of selected graphite materials under highflux plasma bombardment in PISCES-A: - Effects of surface pores and grooves -" Y.Hirooka, R.W.Conn, D.M.Goebel, B.Labombard, W.K.Leung, R.Nygren and Y.Ra

To be published in Journal of Nuclear Materials (Cumently availaible as UCL.A Rep. \#UCLA-PPG-1159).

3. "In-situ spectroscopic measurements of erosion behavior of TFTR-redeposited carbon materials under high-flux plasma bombandment in PISCES-A" Y.Hirooka, A.Pospieszczyk, R.W.Conn, B.Labombard, B.Mills, R.Nygren and Y,Ra To be published in Journal of Vacuum Science \& Technologies-A (Currently available as UCLA Rep. \#UCLA-PPG-1174). 
Table 1. Observations of graphite wall pumping of hydrogen plasmas.

\begin{tabular}{|c|c|c|c|c|c|}
\hline Year & Facility & Component & Graphite & Conditioning & Remarks \\
\hline 1985 & JET & $\begin{array}{l}\text { Inner wall tile } \\
\left(T \approx 300^{\circ} \mathrm{C}\right)\end{array}$ & CL-5890 & $\begin{array}{l}\text { No conditioning } \\
\text { (Pore openings?) }\end{array}$ & $\begin{array}{l}\text { Reproducible } \\
\text { Saturable }\end{array}$ \\
\hline 1986 & TFTR & $\begin{array}{l}\text { Bumper limiter } \\
\left(T<100^{\circ} \mathrm{C}\right)\end{array}$ & $\begin{array}{l}\text { POCO } \\
\text { (AXF-5Q) }\end{array}$ & $\begin{array}{l}\text { He-discharges } \\
\text { (Pore openings) }\end{array}$ & $\begin{array}{l}\text { Saturable* } \\
\text { (10-20 shots) }\end{array}$ \\
\hline 1986 & PISCES & $\begin{array}{l}\text { Porous target } \\
\left(\mathrm{RT}<\mathrm{T}<480^{\circ} \mathrm{C}\right)\end{array}$ & $\begin{array}{l}\text { POCO } \\
\text { (HPD-1) }\end{array}$ & DC He-PAP & $\begin{array}{l}\text { Saturable } \\
\left(2 \times 10^{18} \mathrm{H} / \mathrm{cm}^{2}\right)\end{array}$ \\
\hline 1987 & DIII-D & $\begin{array}{l}\text { Livestor } \\
\left(\mathrm{T}<200^{\circ} \mathrm{C}\right)\end{array}$ & $\begin{array}{l}\text { UCAR } \\
\text { (TS-1792) }\end{array}$ & DC He-glow & $\begin{array}{l}\text { Saturable } \\
\text { (1-10 shots?) }\end{array}$ \\
\hline 1988 & TEXTOR & $\begin{array}{l}\text { ALT-II } \\
\left(T<200^{\circ} \mathrm{C}\right)\end{array}$ & $\begin{array}{l}\text { Mitsubishi } \\
\text { (IG-1 10) }\end{array}$ & DC He-glow & $\begin{array}{l}\text { Saturable } \\
\text { (10 shots?) }\end{array}$ \\
\hline 1988 & PISCES & $\begin{array}{l}\text { Grooved target } \\
\left(T<200^{\circ} \mathrm{C}^{* *}\right)\end{array}$ & $\begin{array}{l}\text { POCO } \\
(\text { AFX-SQ) }\end{array}$ & No conditioning & $\begin{array}{l}\text { Non-saturable*** } \\
\text { (Co-deposition) }\end{array}$ \\
\hline
\end{tabular}

*) Partially attributed to non-saturable pumping due to co-deposition.

**) High temperanure data being investigated in PISCES.

***) 10-20\% continuous reduction of recycling of particles. 
Table 2. Comparison of the plasma pameters in PISCES and tokamaks.

\begin{tabular}{|c|c|c|}
\hline PSI-paramters & PISCES & Tokamaks (edges) \\
\hline Plasma operacion mode & $\begin{array}{l}\text { Continuous } \\
\text { (hours) }\end{array}$ & $\begin{array}{l}\text { Pulse } \\
\text { (up to } 30 \mathrm{~s} \text { ) }\end{array}$ \\
\hline Plasma species & $\mathrm{H}, \mathrm{D}, \mathrm{He}, \mathrm{N}, \mathrm{Ar}$ & $\mathrm{H}, \mathrm{D}, \mathrm{He}$ \\
\hline Plasma density $\left(\mathrm{cm}^{-3}\right)$ & $10^{11}-10^{13}$ & $10^{11}-10^{14}$ \\
\hline Electron temperature (eV) & $5-30$ & $10-200$ \\
\hline Ion temperature (cV) & $=1$ & $10-100$ \\
\hline Ion bombarding energy (eV) & $\begin{array}{l}20-500 \\
\text { (Biasing) }\end{array}$ & $\begin{array}{l}30-600 \\
(-3 k T e)\end{array}$ \\
\hline Ion bombarding flux $\left(\mathrm{cm}^{-2} \mathrm{~s}^{-1}\right)$ & $10^{17}-10^{18}$ & $10^{16}-10^{18}$ \\
\hline Wall temperature $\left({ }^{\circ} \mathrm{C}\right)$ & RT - 1600 & RT $-1500(?)$ \\
\hline Magnietic field (G) & $200-1000$ & $10000-30000$ \\
\hline Ion gyro-radii(mm) & $1-5$ & $0.1-5$ \\
\hline
\end{tabular}




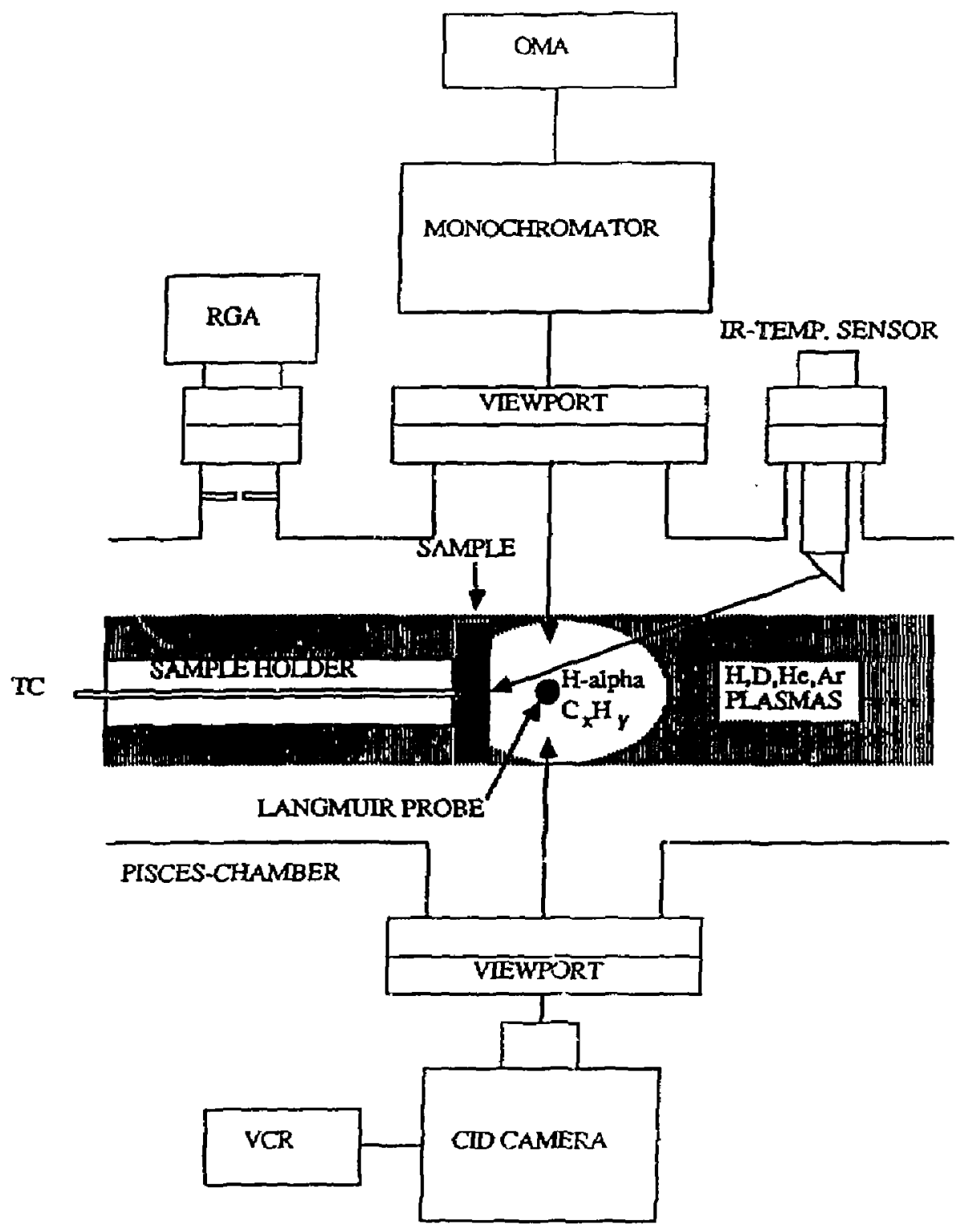

Fig. 1: A schematic diagram of the experimental set up in PISCES-A facility. 


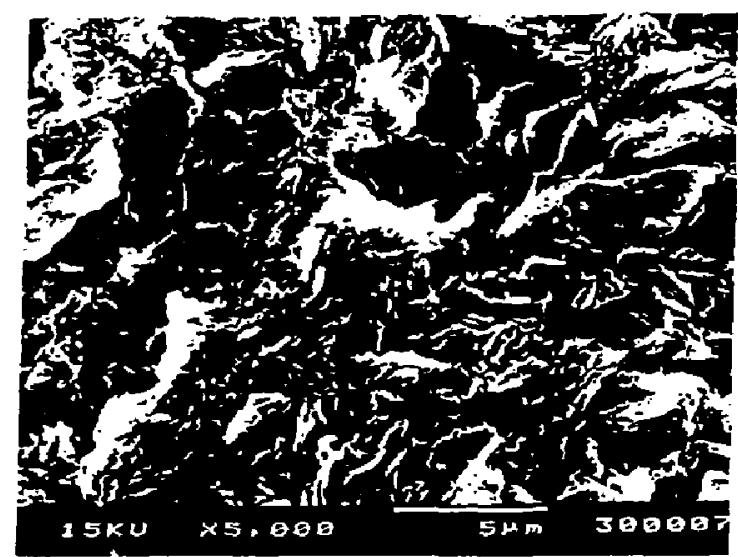

BEFORE PAP

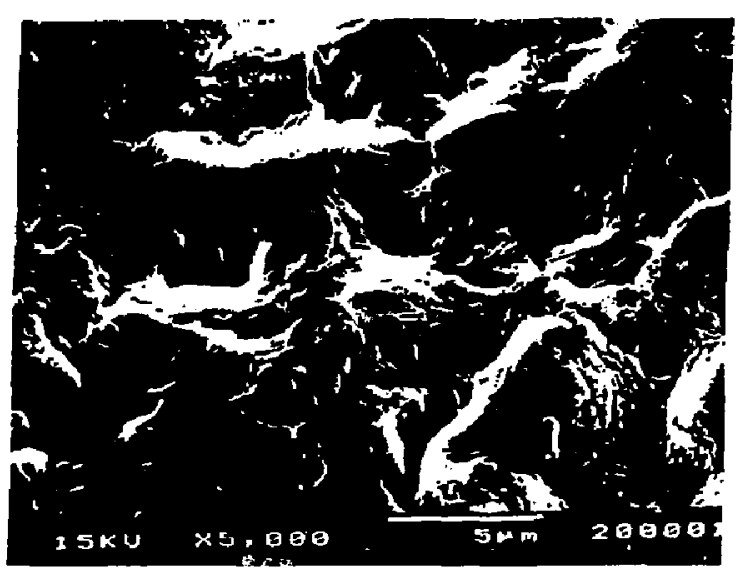

AFTER PAP

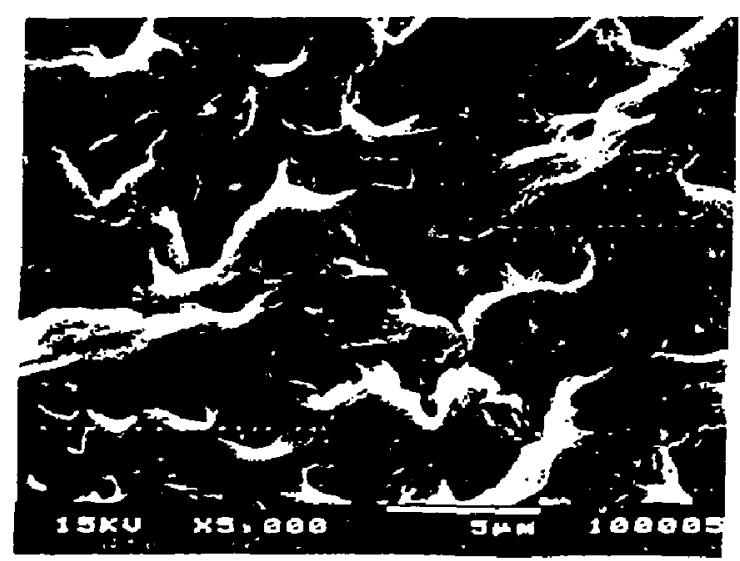

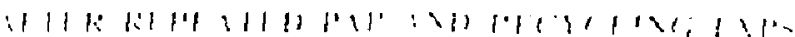

Fig. 2: POCO-graphite surface morpholugies. 


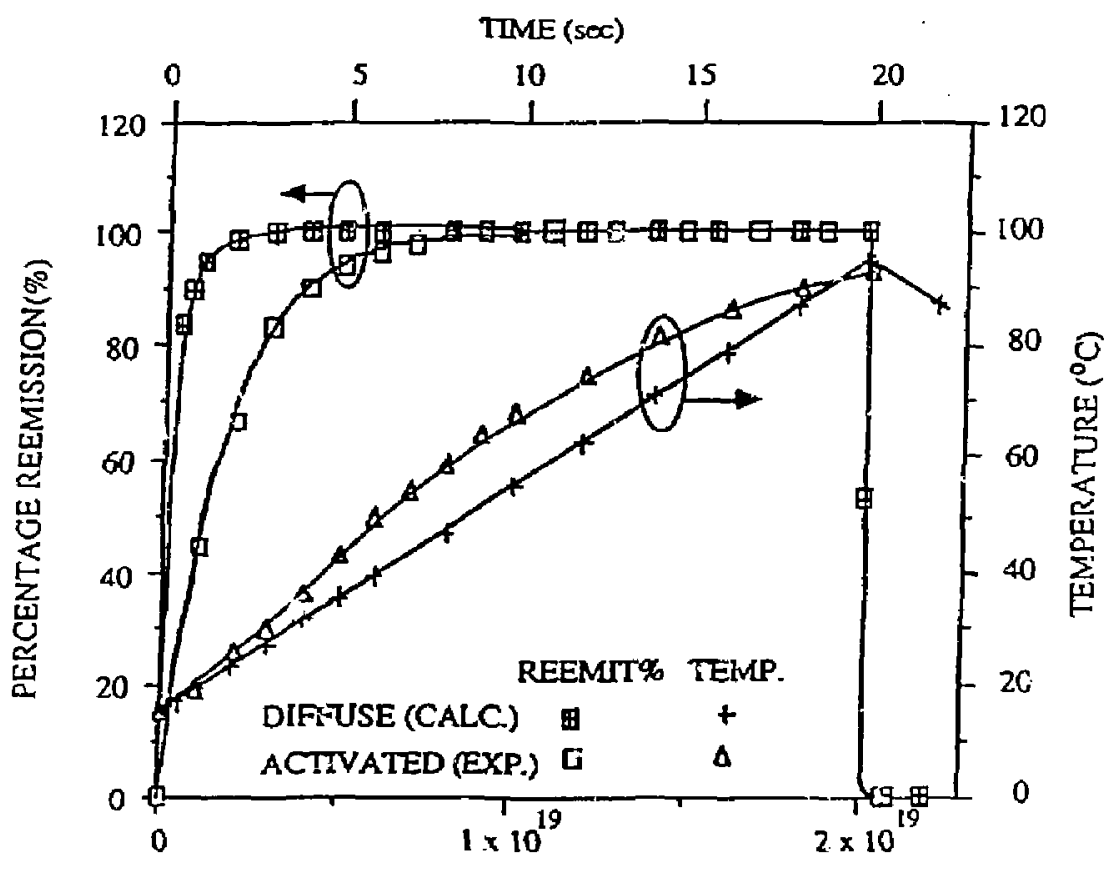

PLASMA BOMBARDMENT FUUENCE (ions/ $\mathrm{cm}^{2}$ )

Fig. 3: Hydrogen pumping data vs. DIFFUSE calculations.

After plasma-activation-process, the POCO-graphite target is tumbarded with hydrogen plasma at $300 \mathrm{eV}$ at a flux of $1 \times 10^{18}$ ions $\mathrm{cm}^{-2} \mathrm{~s}^{-1}$. The recycling behavior i: measured with $\mathbf{H}$-alpha specuoscopy. The activated graphite shows much slower rise to the $100 \%$ reemission than the DIFFUSE calculation. This is clearly indicative of a high reterition of hydrogen. 
(1) TRAPIING SITE INDUCGD PUMIING(SNLL)

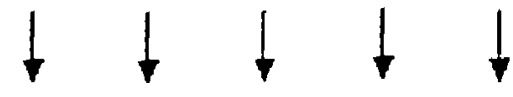

(H) (1) (H) (H)
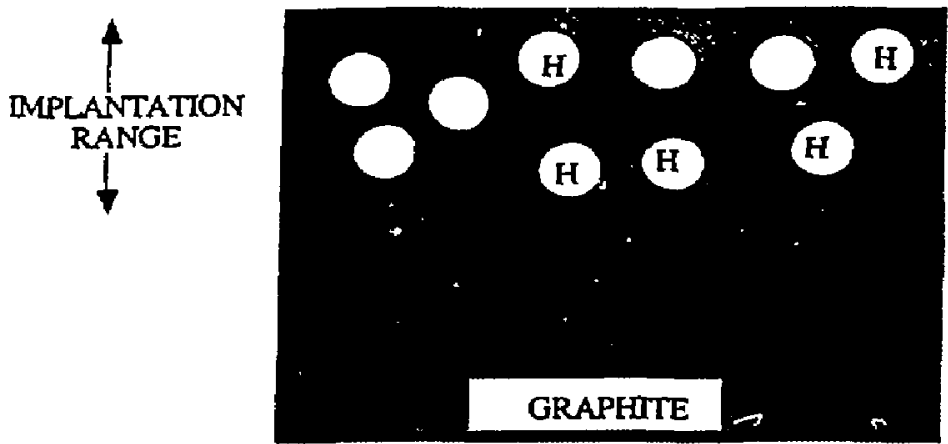

(2) SURFACE POROSITY INDUCED PUMPING (UCLA)
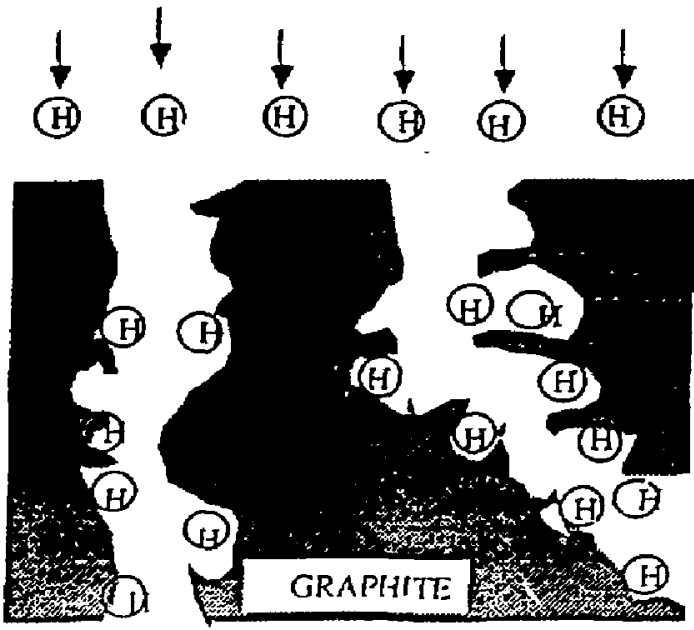

Fig. 4: Porosity-enhanced pumping mechanism. 

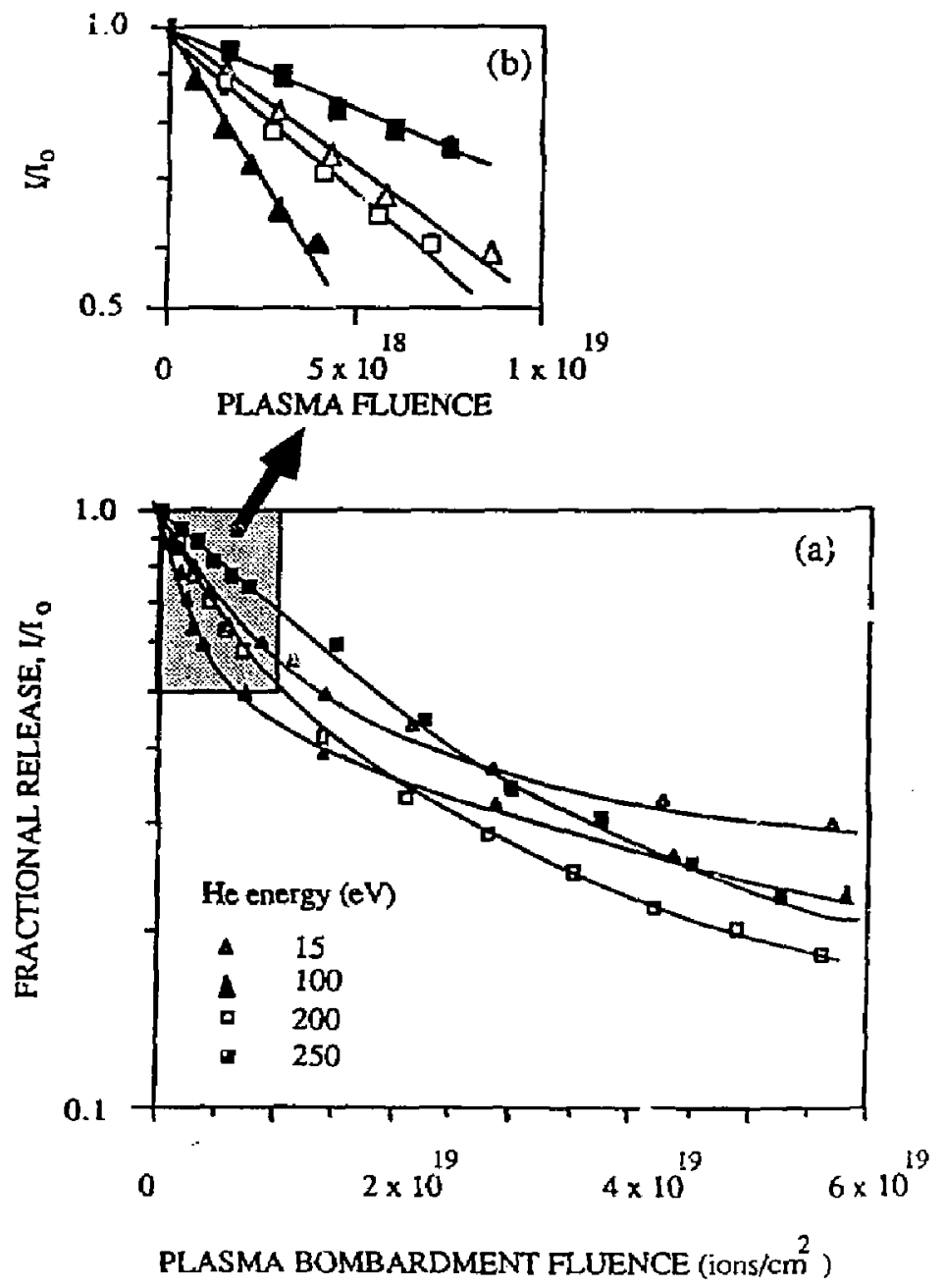

Fig. 5: Hydrogen desorption by He-discharges 


\section{DEUTERIUM PLASMA}
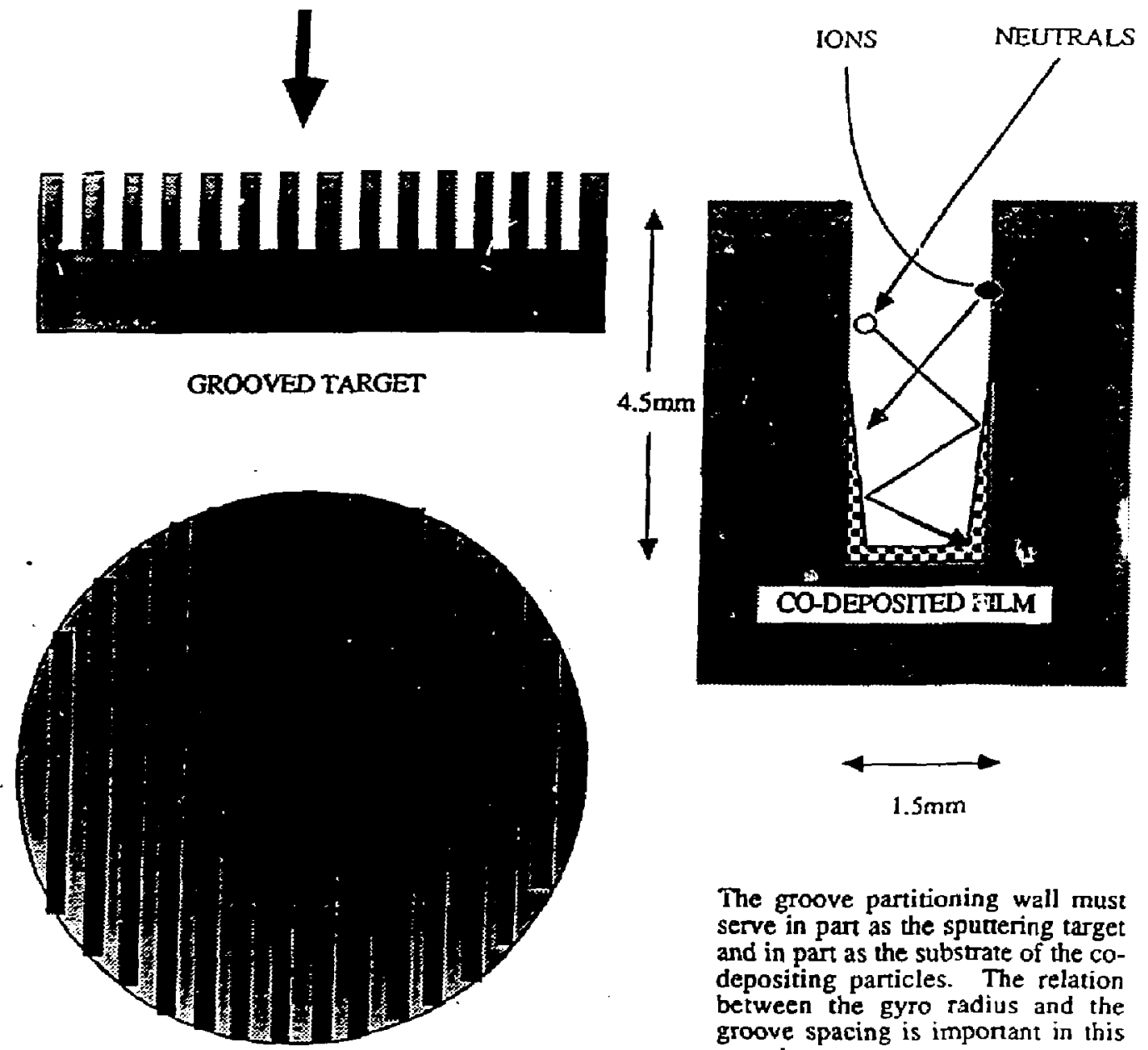

The groove partitioning wall must serve in part as the spunering target and in part as the substrate of the codepositing particles. The relation between the gyro radius and the groove spacing is important in this regard.

$9.5 \mathrm{~cm}$

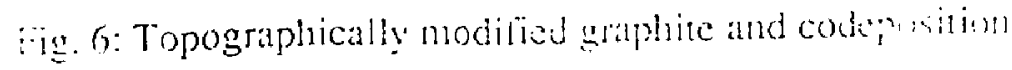



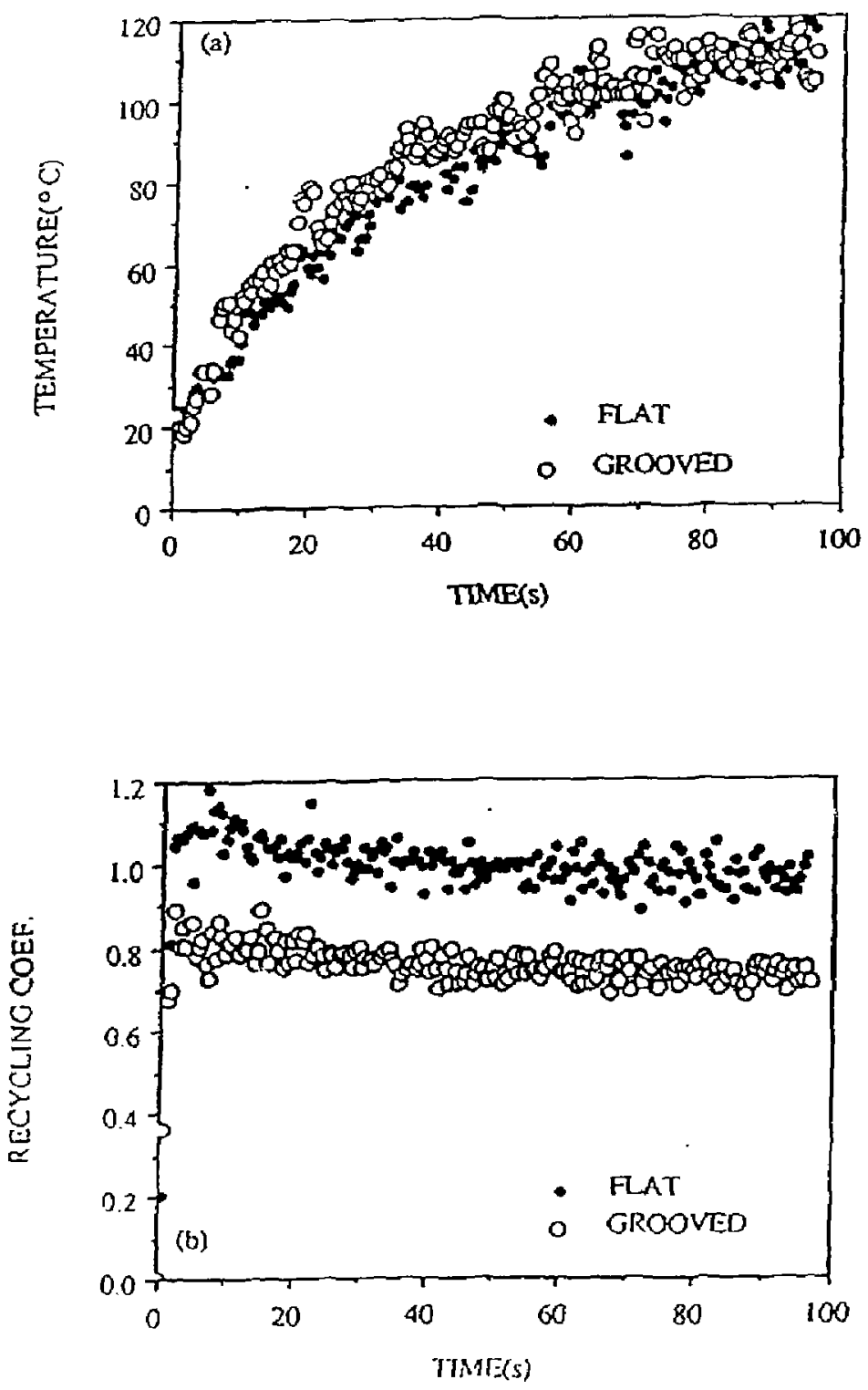

Fig. 7: Non-saturable pumping by surface grooves.

The machine-grooved graphite tirget is bombarded with a deuterium piasma at $300 \mathrm{eV}$ at i thux of $5 \times 10^{17}$ jons $\mathrm{cm}^{-2} \mathrm{~s}^{-1}$. A flat dargel is compared under identical conditions. 


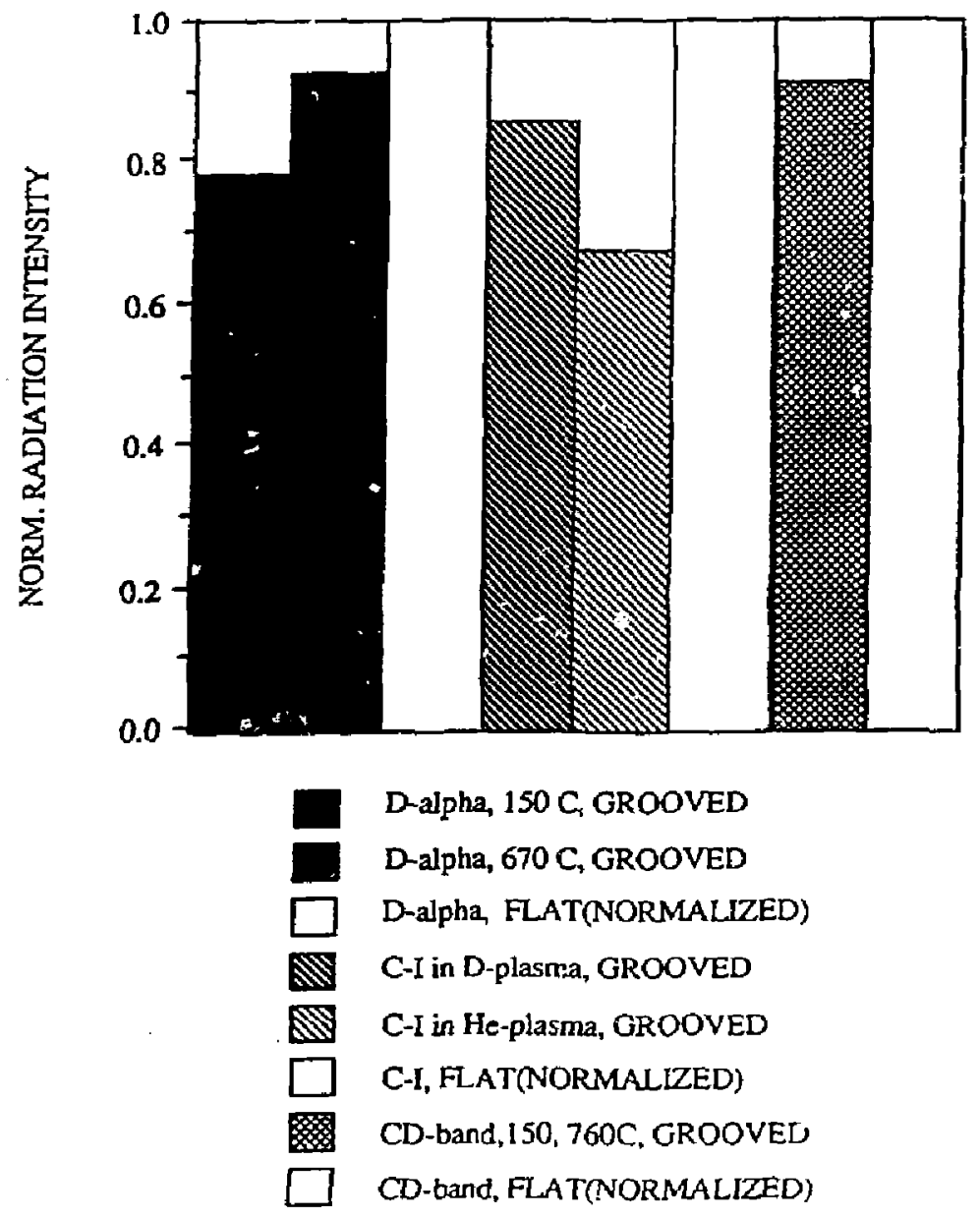

Fig. 8. Reduced emission of impurities. 


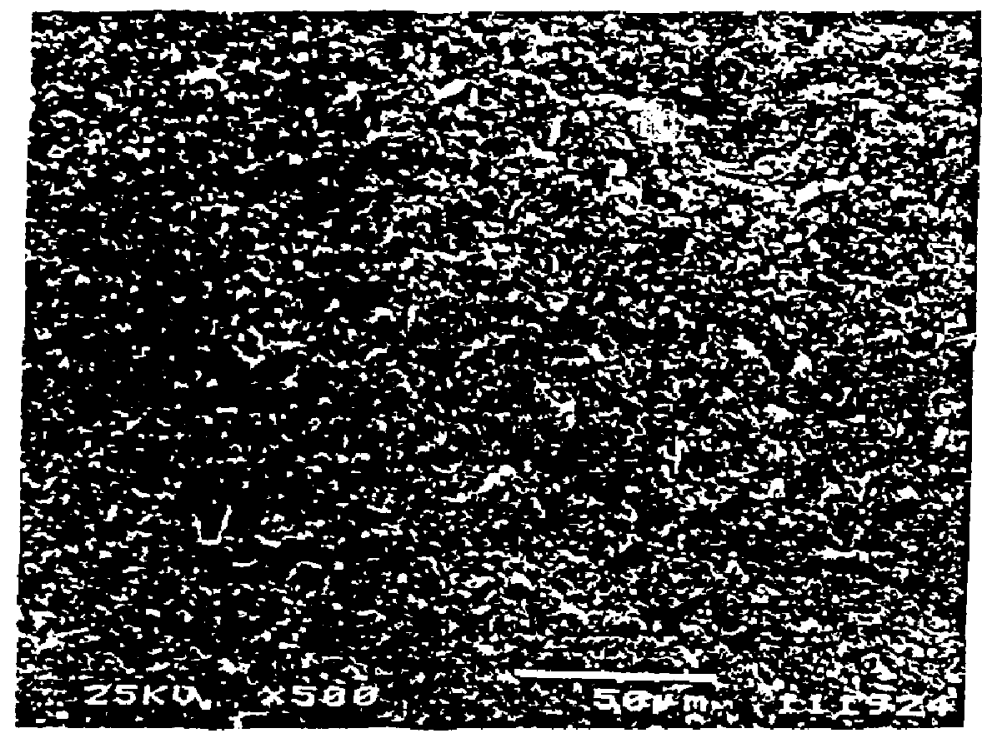

ERODED AREA OF TTHE GROOVE PARTITIONING W:AL

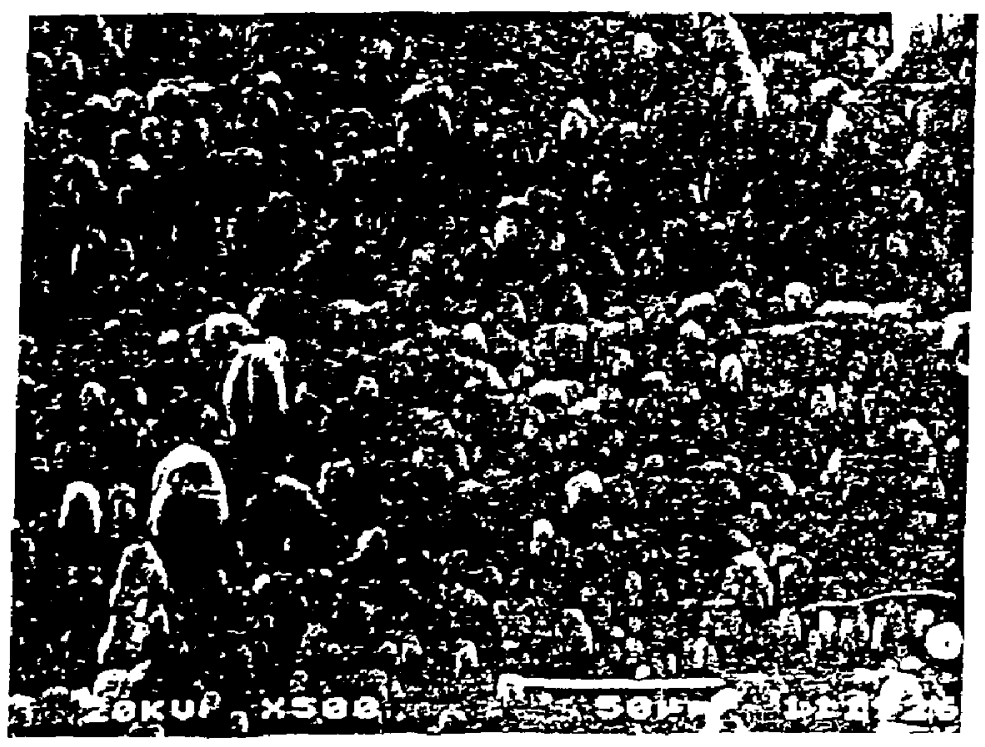

(') ()

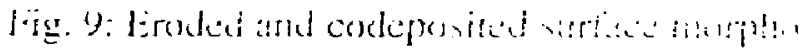




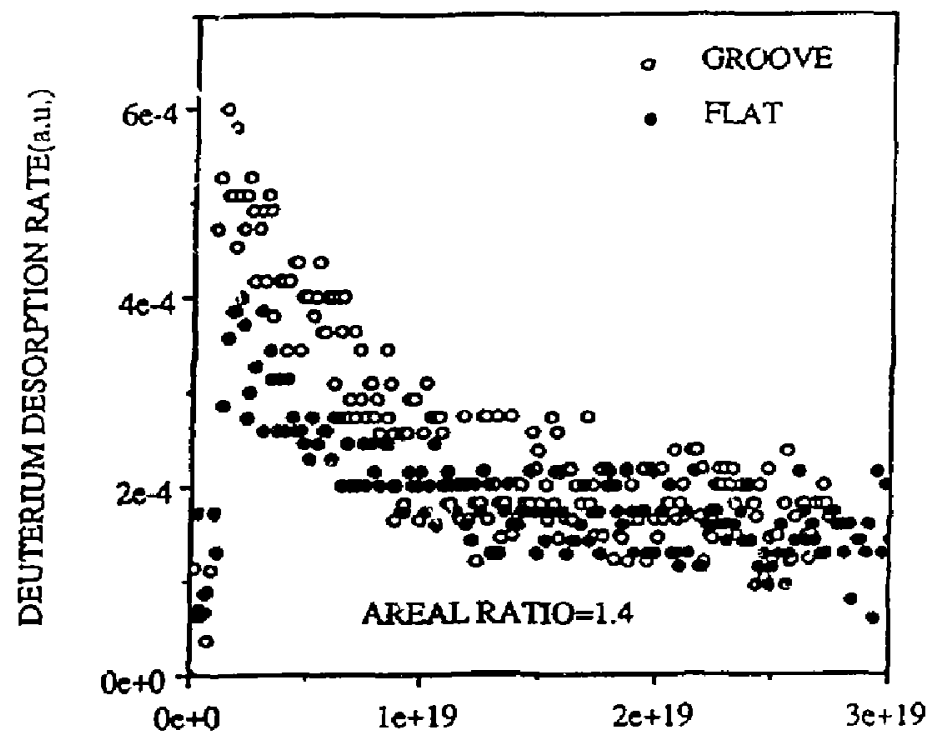

HE-PLASMA FLUENCE(TONS/CM2)

Fig. 10: Deuterium release from grcoves by He-discharges.

The pre-implanted deuterium (at $300 \mathrm{eV}$ ) is released via helium plasma impact desorption at $100 \mathrm{eV}$. The deuterium release behavior is measured with D-alpha spectroscopy. The total amount of released deuterium from the grooved and flat surfaces can be roughly evaluated by comparing the area below the respective release curves. 


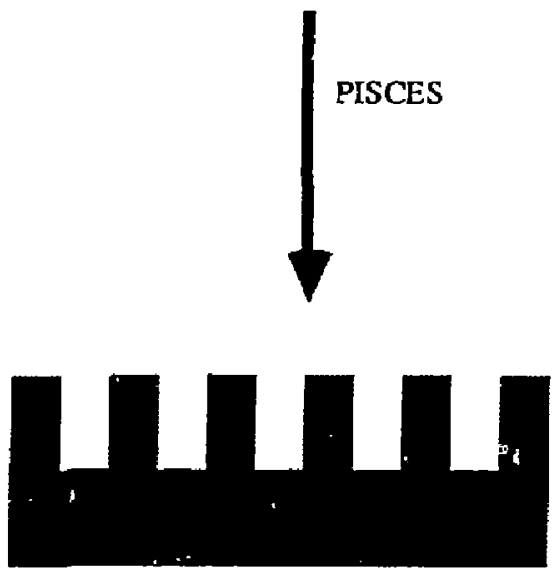

CASE-1

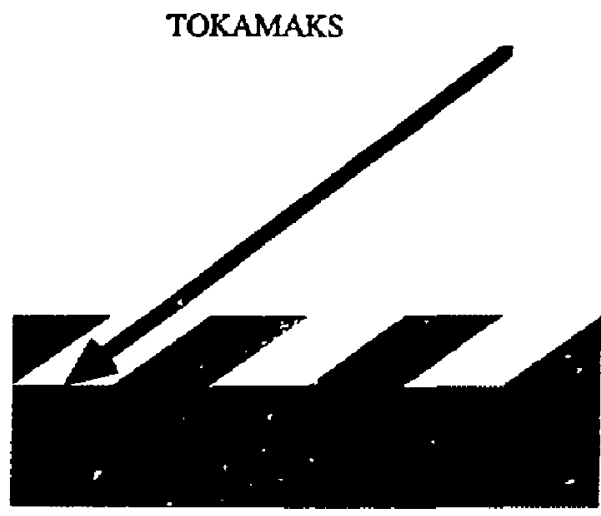

CASE-2

Fig. 11: Non-saturable walls in a toroidal device. 